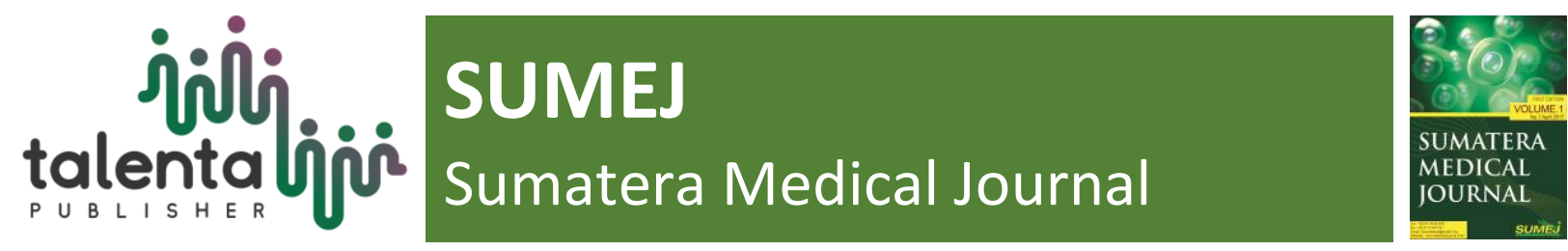

\title{
The Correlation Between Body Mass Index And Acne Vulgaris
}

\author{
G. Z. H. Raditra ${ }^{*}$, M. I. Sari ${ }^{2}$ \\ ${ }^{1}$ Faculty of Medicine, Universitas Sumatera Utara, Medan, North Sumatera, Indonesia \\ ${ }^{2}$ Department of Biochemistry, Universitas Sumatera Utara, Medan, North Sumatera, Indonesia
}

\begin{abstract}
Skin diseases for teenagers and young adults are acne vulgaris. It occurs through various factors, such as food and obesity. Foods with a high glycemic index (IG) are associated with a high incidence of acne vulgaris. By considering the Body Mass Index, the glycemic load has a significant relationship with the occurrence of acne vulgaris. The relationship between BMI and acne vulgaris in the class of 2016 FK USU student population. This study was analytic design with cross sectional design, a sample by 2016 FK USU students. Data collected by conducting a physical examination, measurement of height, weight, determination of BMI, and nutrient intake using the Food Frequency Questioner (FFQ) questionnaire. Data is collected using SPSS program. Then, a Chi-Square test was performed. The incidence of acne vulgaris in students 2016 FK USU was $46.1 \%$. With majority of locations arising acne vulgaris is in the face of $35.6 \%$. The most common age suffering from acne vulgaris is 21 years $(22.2 \%)$. Women $(30.6 \%)$ from acne vulgaris than men $(15.6 \%)$. The most BMI in the sample is underweight to normal body weight $(31.7 \%)$. The results of data analysis, found no relationship between BMI and acne vulgaris $\mathrm{p}=0.336$
\end{abstract}

Keyword: Acne vulgaris, Body Mass Index, Nutrition Intake, Class of 2016 students

Received 4 January 2020 | Revised 16 January 2020 | Accepted 20 January 2020

${ }^{*}$ Corresponding author at: Faculty of Medicine, Universitas Sumatera Utara, Medan, North Sumatera 


\section{Introduction}

Acne Vulgaris (AV) is a self-limiting disease in form of annual inflammation on pilosebaceous units frequently found on adolescents. This disease is identified with eruption of comedones, papules, pustules, nodes and cysts on predilection area: the face, neck, upper arm, chest, and back [1]. In Indonesia, Lehmann classification is used to determine the degree of severity of acne vulgaris. It is divided into 3 categories according to the type and number of the lesions, namely mild, moderate, and severe [2].

There are approximately more than 60 million people suffering from acne globally. In the United States, $85 \%$ of the civilians aged 12-24 years suffer from acne vulgaris and similar data is also discovered on the western part of the world. In Africa, a cross-sectional study reported a prevalence of $90.7 \%$ on adolescents [3]. Generally, acne vulgaris starts to occur on those in 1215 years of age, peaking at those who are 17-21 years old [4].

This disease is facilitated through various factors, for instances genetics, endocrine, food, sebaceous gland activity, bacterial infection, cosmetics, stress, and obesity [5]. Certain food which could induce acne are dairy products, hyperglycemic carbohydrates, as well as lipids. The mentioned food could induce acne through elevated insulin and insulin-like growth factor-1 (IGF-1) [6]. IGF-1 will stimulate hypersecretion of androgens, which are known to participate in acne vulgaris pathogenesis by increasing the sebaceous gland proliferation in the early formation of acne vulgaris [7].

Other associated factor with acne vulgaris is obesity, an accumulation of excess lipids [8]. The prevalence of obesity on adolescents reaches $21 \%$ in Indonesia [9]. With consideration of body mass index (BMI) and gender, glycemic load has a significant relationship with the incidence of acne vulgaris [10].

After the preceding explanation, that acne vulgaris remains highly prevalent on adolescents and tends to occur on people with high BMI, the authors aimed to assess the association between BMI and acne vulgaris on fourth-year students of Medical Faculty, Universitas Sumatera Utara (USU).

\section{Method}

This is an analytical research with cross-sectional design to evaluate the association between body mass index and acne vulgaris. It was carried out from March to December 2019 after receiving ethical clearance from the Ethics Commission of Medical Faculty, USU with letter number 12/TGL/KEPK FK USU/2019. The research involved all students of Medical Faculty, USU who were in their fourth-year and fulfilled the inclusion criteria.

The data collection was implemented with consecutive sampling (non-probability sampling) where all the subjects who came in order and fulfilled the inclusion criteria were taken as 
samples until the required number was reached. The obtained data were then analyzed utilizing Statistical Product Service Solution for Windows (SPSS) and tested with Chi-Square test to assess the association between two or more variables.

\section{Result}

This research was carried out on 180 research subjects, fourth-year medical students of USU who fulfilled the inclusion criteria. The recorded characteristics of the samples were age, gender, BMI, acne vulgaris incidence, eruption site, family history, and diet.

Table 1. Frequencies of Characteristics Respondent

\begin{tabular}{lcc}
\hline \multicolumn{1}{c}{ Characteristics } & Frequency & \% \\
\hline Age & 4 & 2,2 \\
19 year & 63 & 35 \\
20 year & 96 & 53,3 \\
21 year & 13 & 7,2 \\
22 year & 4 & 2,2 \\
23 year & & \\
Gender & 67 & 37,2 \\
Male & 113 & 62,8 \\
Female & & 8,3 \\
\hline BMI & 15 & 63,9 \\
Underweight & 115 & 27,8 \\
Normal & 50 & \\
Overweight/Obesity &
\end{tabular}

On table 1 , it could be seen that the average age of the respondents was 19-23 years. The majority of the samples were 21 years old, as many as 96 people (53.3\%), while the fewest ones were 19 and 23 years old, accounting for 4 respondents (2.2\%) each. Based on gender, this research was predominated by female, 113 people (62.7\%), whereas the other 67 (37.2\%) were male. According to BMI, most of the samples had normal body weight, as many as 115 people (64\%). The fewest ones who accounted for only 15 people were underweight $(8 \%)$. 
Table 2. Frequencies of Respondent Based on Acne Vulgaris

\begin{tabular}{lcc}
\hline Acne vulgaris & Frequency & \% \\
\hline Acne vulgaris (+) & 83 & 46,1 \\
Acne vulgaris (-) & 97 & 54,9 \\
\hline Total & 180 & 100 \\
\hline
\end{tabular}

According to table 2 of acne vulgaris incidence, it was found that 83 samples $(46.1 \%)$ suffered from acne. The prevalence of acne vulgaris was $46.1 \%$.

Table 3. Characteristics of Sample Based on Acne Vulgaris Location

\begin{tabular}{lcc}
\hline \multicolumn{1}{c}{ Location of Acne } & Frequencies & \% \\
\hline Face & 64 & 35,6 \\
Face, Chest & 3 & 1,7 \\
Face, Upper Arm & 2 & 1,1 \\
Face, Back & 10 & 5,6 \\
Face, Neck & 2 & 1,1 \\
Face, Neck, Back & 2 & 1,1 \\
Not Suffer & 97 & 53,9 \\
\hline Total & 180 & 100 \\
\hline
\end{tabular}

According to table 3 of the eruption site of acne vulgaris, most of the samples had acne vulgaris on their faces, as many as 64 people $(35.6 \%)$.

Table 4. Characteristics of Acne Vulgaris Based on Family History

\begin{tabular}{lcccccc}
\hline \multirow{2}{*}{ Family Member } & \multicolumn{4}{c}{ Acne Vulgaris } & \multicolumn{2}{c}{ Total } \\
\cline { 2 - 5 } & \multicolumn{2}{c}{ Suffer } & \multicolumn{2}{c}{ Not Suffer } & & \\
\cline { 2 - 6 } & $\mathbf{N}$ & $\mathbf{\%}$ & $\mathbf{N}$ & $\%$ & $\mathbf{N}$ & $\%$ \\
\hline Father/Mother & 23 & $12,8 \%$ & 7 & $3,9 \%$ & 30 & $16,7 \%$ \\
Brother/Sister & 29 & $16,1 \%$ & 36 & $20 \%$ & 65 & $36,1 \%$ \\
Father/Mother, & 15 & $8,3 \%$ & 7 & $3,9 \%$ & 22 & $12,2 \%$ \\
Brother/Sister & 16 & $8,9 \%$ & 4 & $2,2 \%$ & 20 & $11,1 \%$ \\
Others & 0 & $0 \%$ & 43 & $23,9 \%$ & 43 & $23,9 \%$ \\
No one & 83 & 46,1 & 97 & 53,9 & 180 & 100 \\
\hline Total & & & & & & \\
\hline
\end{tabular}


Table 4 presented 83 samples $(46.1 \%)$ with family history on those who suffered from acne vulgaris. Whereas among those without acne vulgaris, only 54 samples $(30 \%)$ had family history.

Table 5. Characteristics of Acne Vulgaris Based on Age

\begin{tabular}{lcccccc}
\hline \multirow{2}{*}{ Age } & \multicolumn{4}{c}{ Acne Vulgaris } & \multicolumn{2}{c}{ Total } \\
\cline { 2 - 5 } & \multicolumn{2}{c}{ Suffer } & \multicolumn{2}{c}{ Not Suffer } & & \\
\cline { 2 - 6 } & $\mathbf{N}$ & $\mathbf{\%}$ & $\mathbf{N}$ & $\mathbf{\%}$ & $\mathbf{N}$ & $\mathbf{\%}$ \\
\hline 19 years & 1 & $0,6 \%$ & 3 & $1,7 \%$ & 4 & $2,2 \%$ \\
20 years & 30 & $16,7 \%$ & 33 & $18,3 \%$ & 63 & $35 \%$ \\
21 years & 40 & $22,2 \%$ & 56 & $31,1 \%$ & 96 & $53,3 \%$ \\
22 years & 8 & $4,4 \%$ & 5 & $5,2 \%$ & 13 & $7,2 \%$ \\
23 years & 4 & $2,2 \%$ & 0 & $0,0 \%$ & 4 & $2,2 \%$ \\
\hline Total & 83 & 46,1 & 97 & 53,9 & 180 & 100 \\
\hline
\end{tabular}

On table 5, it was discovered that on 83 students $(46.1 \%)$ with acne vulgaris, most were 21 years old $(31.3 \%)$ and the youngest ones were 19 years old $(0.6 \%)$.

Table 6. Characteristics of Acne Vulgaris Based on Gender

\begin{tabular}{lcccccc}
\hline \multirow{2}{*}{ Gender } & \multicolumn{4}{c}{ Acne Vulgaris } & \multicolumn{2}{c}{ Total } \\
\cline { 2 - 6 } & \multicolumn{2}{c}{ Suffer } & \multicolumn{2}{c}{ Not Suffer } & & \\
\cline { 2 - 6 } & $\mathbf{N}$ & $\mathbf{\%}$ & $\mathbf{N}$ & $\mathbf{\%}$ & $\mathbf{N}$ & $\mathbf{\%}$ \\
\hline Male & 28 & $15,6 \%$ & 39 & $21,7 \%$ & 67 & $37,2 \%$ \\
Female & 55 & $30,6 \%$ & 58 & $32,2 \%$ & 113 & $62,8 \%$ \\
\hline Total & 83 & 46,1 & 97 & 53,9 & 180 & 100 \\
\hline
\end{tabular}

Table 6 showed that the majority suffering from acne vulgaris were female students by $30.6 \%$, while the male ones with acne vulgaris only accounted for $15.6 \%$. 
Tabel 7. Relation Between BMI and Acne Vulgaris

\begin{tabular}{|c|c|c|c|c|c|c|c|}
\hline \multirow{3}{*}{ BMI } & \multicolumn{4}{|c|}{ Acne Vulgaris } & \multirow{2}{*}{\multicolumn{2}{|c|}{ Total }} & \multirow{3}{*}{$\begin{array}{c}p \\
\text { value }\end{array}$} \\
\hline & \multicolumn{2}{|c|}{ Suffer } & \multicolumn{2}{|c|}{ Not Suffer } & & & \\
\hline & $\mathbf{N}$ & $\%$ & $\mathbf{N}$ & $\%$ & $\mathbf{N}$ & $\%$ & \\
\hline Obesity & 26 & $14,4 \%$ & 24 & $13,3 \%$ & 50 & $27,8 \%$ & \\
\hline Non-Obesity & & & & & & & 0,326 \\
\hline $\begin{array}{l}\text { (Underweight- } \\
\text { Normal) }\end{array}$ & 57 & $31,7 \%$ & 73 & $40,6 \%$ & 130 & $72,2 \%$ & \\
\hline Total & 83 & $46,1 \%$ & 97 & $53,9 \%$ & 180 & $100,0 \%$ & \\
\hline
\end{tabular}

Table 7 of the association between BMI and acne vulgaris on 180 respondents indicated that those who were not obese (31.7\%) were more frequent to suffer from acne vulgaris compared to those who were overweight/obese (14.4\%).

Table 8. Frequencies of Respondent Intake in Last 1 Month

\begin{tabular}{llccccccc}
\hline No Food Material & \multicolumn{3}{c}{ Often } & \multicolumn{3}{c}{ Rare } & \multicolumn{3}{c}{ Never } \\
\cline { 3 - 9 } & & $\mathbf{n}$ & $\mathbf{\%}$ & $\mathbf{n}$ & $\mathbf{\%}$ & $\mathbf{n}$ & $\mathbf{\%}$ \\
\hline 1 Side Dish & & & & & & \\
Rice & 174 & 96,7 & 6 & 3,3 & 0 & 0,0 \\
Noodle & 10 & 5,6 & 93 & 51,7 & 77 & 42,8 \\
Potato & 7 & 3,9 & 72 & 40,0 & 101 & 56,1 \\
Bread & 26 & 14,4 & 85 & 47,2 & 69 & 38,3 \\
Cereal & 10 & 5,6 & 33 & 18,3 & 137 & 76,1
\end{tabular}

2 Beans and their processed product

Green beans

Peanuts

Tofu

Tempeh

3 Milk and their processed product

Milk

Yoghurt

Cheese

$\begin{array}{llllll}1 & 6 & 13 & 7,2 & 166 & 92,2 \\ 1 & 6 & 26 & 14,4 & 153 & 85 \\ 8 & 4,4 & 107 & 59.4 & 65 & 36,1 \\ 19 & 10,6 & 130 & 72,2 & 31 & 17,2\end{array}$

$\begin{array}{llllll}59 & 32,8 & 91 & 50,6 & 30 & 16,7\end{array}$

$\begin{array}{llllll}14 & 7,8 & 58 & 32,2 & 108 & 60\end{array}$

$\begin{array}{llllll}12 & 6,7 & 72 & 40 & 96 & 53,3\end{array}$ 
Ice cream

\section{Snack}

\begin{tabular}{lllllll} 
Fried food & 33 & 18,3 & 90 & 50 & 57 & 31,7 \\
Pasta & 7 & 3,9 & 53 & 29,4 & 120 & 66,7 \\
Fried chicken & 19 & 10,6 & 112 & 62,2 & 49 & 27,2 \\
French fries & 7 & 3,9 & 87 & 48,3 & 86 & 47,8 \\
Meatballs & 1 & 6 & 57 & 31,7 & 122 & 67,8 \\
Donut & 6 & 3.3 & 51 & 28,3 & 123 & 68,3 \\
Cake & 7 & 3,9 & 66 & 36,7 & 107 & 59,4 \\
Chocolate & 20 & 11,1 & 81 & 45,0 & 79 & 43,9 \\
Soft Drink & 7 & 3,9 & 25 & 13,9 & 148 & 82,2 \\
\hline
\end{tabular}

Based on table 8 of frequency distribution of respondents' diet in the last 1-month period, the most common consumed food, by 174 samples (96.7\%), was rice. The most frequently consumed snack was fried food, 33 samples (18.3\%), and the most common drink was coke, accounting for 7 samples (3.9\%).

\section{Discussion}

On table 2, there were 83 (46.1\%) out of 180 samples with acne vulgaris. The prevalence was as high as $46.1 \%$. This corresponds to the previous research, which yielded acne vulgaris prevalence of $57.8 \%$ on students at SMA Negeri 7 Medan [11].

On table 3, according to the eruption site of acne vulgaris, the majority of acne vulgaris was found on the faces (35.6\%). This corresponds to an article, which reported that acne vulgaris commonly occurred on the area with many sebaceous glands, such as: the face, neck, upper arm, chest, and back [1].

On table 4, there were 83 samples (46.1\%) suffering from acne vulgaris who had family history. Whereas those without acne vulgaris yet had family history only accounted for 54 samples (30\%). This is correlated to an article, which stated that acne vulgaris was a genetic disease caused by increase in pilosebaceous unit sensitivity to normal androgen level [12].

On table 5, out of 83 students (46.1\%) with acne vulgaris, most respondents were 21 years old $(31.1 \%)$ and the youngest ones were 19 years old $(0.6 \%)$. The incidence of acne vulgaris generally started in puberty/pre-puberty (12-15 years), occurred on almost all adolescents aged 13-19 years and peaked in age 17-21 years [13].

On table 6, based on gender, the most common ones to suffer from acne vulgaris were females $(30.6 \%)$, while the males only accounted for $15.6 \%$. A research by Manarisip also showed 
similar result, that the majority of the respondents suffering from acne vulgaris were women, as many as 31 people $(86.1 \%)$ [14].

On table 7 of the association between BMI and acne vulgaris among 180 respondents, the nonobese samples were more frequently found to have acne vulgaris (31.7\%) compared to overweight/obese ones (14.4\%). This corresponds to a research by Astutiningsih, 2014 on 62 students at SMA Negeri 3 Kelaten which reported 56.5\% of the samples with acne vulgaris had normal or underweight (non-obese) BMI [15].

In this research, a p-value of 0.336 was obtained, inferring no association between BMI and acne vulgaris. This is correlated to a research by Kristiani in 2017 which stated no relationship between BMI and acne vulgaris incidence on students at SMA Frater Don Bosco Manado with a p-value of 0,233 [16]. Despite so, the result of this research does not correspond to the result from a research by Deliana, 2019 which reported that there was an association between BMI and acne vulgaris on students at SMA Negeri 7 Medan $(\mathrm{p}<0.05)$ [11]. The different results could be caused by some uncontrolled contributing factors, for instances difference in inclusion and exclusion criteria, age ranges, and other factors affecting the incidence of acne vulgaris yet not being assessed in the research, such as hormones [17].

On table 8 of the frequency distribution of respondents' diet in the last 1-month period, the most common food being consumed was rice, 174 samples (96.7\%), most consumed snack was fried food, 33 samples (18.3\%), and the most frequent drink was coke, as many as 7 samples (3.9\%). In the previous research, it was discovered that food with high glycemic index could affect the formation and severity of acne [18]. However, a research by Panjaitann et al (2010) found that there was no association of glycemic index and glycemic load with Insulin Growth Factor-1 (IGF-1) level on patients with acne vulgaris [19]. Diet has long been an issue among dermatologists, some agree and some other disagree [1].

\section{Conclusion}

From the results of the statistical analysis utilizing Chi-Square test, a p-value larger than $\alpha$ was obtained ( $\mathrm{p}$-value $=0.336>\alpha=0.05$ ). Thus, it could be concluded that there is no association between BMI and acne vulgaris incidence among fourth-year medical students of USU Medan. Acne vulgaris was found on $46.1 \%$ of the students and most was located on their faces $(35.6 \%)$. The most frequent group to suffer from acne vulgaris was those aged 21 years $(22.2 \%)$. Females (30.6\%) were more prone to acne vulgaris compared to males $(15.6 \%)$.

\section{REFERENCES}

[1] Wasitaatmadja, S.M. 2011, Dermatology Kosmetik. Penuntun Ilmu Kosmetik Medik. Edisi kedua.Jakarta : Fakultas Kedokteran Universitas Indonesia.

[2] Misery, L., Wolkenstein, P., Amici, J. M. 2015, 'Consequences of Akne on Stress, Fatique, Sleep Disorders and Sexual Activity : A Population-based study', Acta Dermato- 
Venereologica, vol. 95, pp. 485-488.

[3] Husein, Y. 2009, Acne Vulgaris In Nigeria Adolescent: prevalence, severity, beliefs, perceptions and practices. International Journal of Dermatology; 48:498-505 .

[4] Sihotang, I.B., Wasitatmadja, S.M. (2016). 'Akne vulgaris', in Menaldi, S.L., Bramono, K., Indriani, W. (eds). Ilmu penyakit kulit dan kelamin. $7^{\text {th }}$ ed. Jakarta: Badan Penerbit FK UI pp. $288-291$.

[5] Movita, T. 2013, 'Akne Vulgaris', Continuing Medical Education, vol. 40, no. 4, pp. 269272.

[6] Melnik, B.C. 2015, Linking diet to acne metabolomics, inflammation, and comedogenesis : an Update. Clin Cosmet Investig Dermatol. Jul 15;8:371- 88.

[7] Katta, R. dan Desai, S.P. 2014, Diet and dermatology : The role of dietary intervention in skin disease. Clin Dermatol. 7(7): 46-51.

[8] World Health Organization. 2016, Obesity and overweight. Geneva: WHO; 2016 Available from http://www.who.int

[9] Departement Kesehatan Indonesia. 2013, Gizi Seimbang Atasi Masalah Gizi Ganda. Available from: http://www.depkes.go.id/article/print/2239/gizi-seimbang-atasi-masalahgizi-ganda.html

[10] Ismail, N.H., Zahara, A.M., dan Noor, Z.A. 2012, High Glycemic Load Diet, Milk and Ice Cream Consumption Are Related to Acne Vulgaris in Malaysian Young Adult : a case control study. BMC Dermatology. 12:13 .

[11] Deliana, R., Amalia, R., dan Jusuf, N.K. 2019, Hubungan Indeks Massa Tubuh dengan Akne Vulgaris pada Siswa-Siswi SMA Negeri 7 Medan.

[12] Effendi, Z, 2003 peran Kulit dalam Mengatasi Akne Vulgaris. Available from : http://repository.usu.ac.id/bitsteam/123456789/3565/1 /histologi-zukesti3.pdf

[13] Wasitaatmadja, S.M. 2018, Kelompok Studi Dermatologi Kosmetik Indonesia. Akne. Jakarta : Fakultas Kedokteran Universitas Indonesia.

[14] Manarisip, C. K., Kepel, B. J., Rompas, S. S. 2015, 'Hubungan Stres dengan Acne Vulgaris pada Mahasiswa Semester V (Lima) Program Studi Ilmu Keperawatan Fakultas Kedokteran Universitas SAM Ratulangi Manado', e-Journal Keperawatan, vol. 3, no. 1, pp. 1-6.

[15] Astutiningsih S. 2014, Hubungan antara indeks massa tubuh (IMT) dengan timbulnya akne vulgaris pada siswa-siswi SMA Negeri 3 Klaten [Skripsi]. Surakarta: Fakultas Kedokteran Universitas Muhammadiyah.

[16] Kristiani, N.M., Kapantouw M.G., dan Pandaleke T.A.2017, Hubungan Indeks Massa Tubuh dan Angka Kejadian Akne Vulgaris pada Siswa-siswi di SMA Frater Don Basco Manado.

[17] Alan, S., and Cenosizoglu, E. 2014, 'Effects of hyperandrogenism and high body mass index on acne severity in women', Saudi Med J, vol. 35 no. 8 pp. 886-889. [Online], accessed 17 November 2017, available at: https://www.ncbi.nlm.nih.gov 
[18] Smith, R.N., Mann, N.J., Braue, A., Makkelainen, H., Varigos, G.A.2007. A lowglycemic-load diet improves symptoms in acne vulgaris patients: a randomized controlled trial 1,2,3. American Society for Clinical Nutrition.

[19] Panjaitan, R.R., Tala, Z.Z., Jusuf, N.K. 2010, Hubungan Antara Indeks Glikemik dan Beban Glikemik dengan Insulin-Like Growth Factor-1 pada pasien Akne Vulgaris. MDVI 